\title{
A Numerical Investigation on the Structural Behavior of Deficient Steel Frames Strengthened using CFRP Composite
}

\author{
Keykha, A.H..$^{*}$
}

\begin{abstract}
Carbon fiber reinforced polymers (CFRP) is one of the materials that is used to strengthen steel structures. Most studies on CFRP strengthening steel on structures have been done on beams and steel columns. No independent study has studied the effect of CFRP strengthening on the structural behavior of steel frames having initial deficiency. The deficiency in steel structures may be created due to the errors caused by construction and others. This study aims to carry out a numerical study on the efficiency of CFRP sheet on strengthening square hollow section (SHS) steel frames having initial deficiency. Seven specimens, five of which were strengthened using CFRP sheets, were analyzed. ANSYS software was used to analyze the SHS steel frames. The results showed that the coverage length, the width, and the number of CFRP layers have a significant effect on increasing and recovering the ultimate load capacity of the SHS steel frames having initial deficiency.
\end{abstract}

Keywords: CFRP strengthening; deficient steel frames; numerical study; ultimate load capacity.

\section{Introduction}

Carbon fiber reinforced polymer (CFRP) is preferred to strengthen and retrofit hollow steel sections, due to its much higher elastic modulus and ability to be applied to any shape of structure. Over the past decades, some studies have been done on strengthening and retrofitting of steel columns [1-8]. Some other studies have been done on flexural strengthening, shear, tensile, and torsional of steel beams [914]. Sundarraja and Prabhu [15] strengthened the hollow steel beams, which were first filled with concrete, using CFRP composites, and then they tested these steel beams. The beams strengthened by full coverage of CFRP sheet exhibited more enhancements in stiffness and moment capacity than other strengthened beams. They also presented an economical method for strengthening of the hollow steel beams that were filled with concrete. In a similar study, Al Zand et al. [16] strengthened the square CFST (concrete-filled steel tube) beams. The results showed that, for all strengthened CFST models using one layer of CFRP sheet, CFRP had no significant enhancement in the ultimate load capacity when wrapped along 50,75 , and $100 \%$ of the length of the specimens.

\footnotetext{
${ }^{1}$ Department of Civil Engineering, Zahedan Branch, Islamic Azad University, Zahedan, IRAN.

* Corresponding author: ah.keykha@iauzah.ac.ir
}

Note: Discussion is expected before June, $1^{\text {st }} 2018$, and will be published in the "Civil Engineering Dimension", volume 20, number 2, September 2018.

Received 19 July 2016; revised 10 February 2018; accepted 20 February 2018.
In other studies, Keykha et al. [17-19] investigated the SHS steel columns strengthened with the use of adhesively bonded CFRP flexible sheets under a combination of flexural moment and compression load. The results showed that the CFRP composite had no similar effect on the behavior of the slender and stocky SHS steel columns under the combined loads. The results also showed that the coverage length, the number of layers, and the location of CFRP composites had a significant effect on increasing the ultimate load capacity of the SHS steel columns under the combined loads.

Keykha [20-23] investigated the structural behaviors of SHS steel members having initial longitudinal or transverse deficiencies which were strengthened using CFRP sheets. The results showed that the impact of transverse deficiency on the ultimate load capacity of steel members is higher than the longitudinal one. The results also showed that CFRP sheet can recover the ultimate load capacity of the SHS steel members having initial deficiency.

From the past studies, one can conclude that no study has investigated the use of CFRP as a strengthening material for the SHS steel frames having initial deficiency. Thus the main focus of the study is the numerical investigation of CFRP strengthening on the behaviors of the SHS steel frames having initial deficiency. Initial deficiency considered in the steel frames was an artificial crack with a length of $100 \mathrm{~mm}$, width $5 \mathrm{~mm}$, and depth 50 $\mathrm{mm}$ at mid-span on tension side of these frame. The coverage length, the number of layers, and the width of CFRP sheet were varied to examine the ultimate load capacity of the deficient steel frames. 


\section{Materials Used}

The SHS steel having a dimension of $100 \mathrm{~mm} \times 100$ $\mathrm{mm}$ was used in this study. The thicknesses for column and beam of the SHS steel frames were 10 $\mathrm{mm}$ and $5 \mathrm{~mm}$, respectively. The SHS steel had a yield stress of $280 \mathrm{~N} / \mathrm{mm}^{2}$, an ultimate stress of 375 $\mathrm{N} / \mathrm{mm}^{2}$, and the modulus of elasticity about 200000 $\mathrm{N} / \mathrm{mm}^{2}$ which were obtained from the experimental values in Keykha et al. [7].

For CFRP strengthening of the SHS steel frames having initial deficiency, Sika Wrap-230C was used. It is a unidirectional carbon fiber reinforced polymer with a nominal modulus of elasticity of 238000 $\mathrm{N} / \mathrm{mm}^{2}$, a nominal tensile strength of $4300 \mathrm{~N} / \mathrm{mm}^{2}$, and a nominal thickness of $0.131 \mathrm{~mm}$. The Information is provided by the manufacturer.

The adhesive used for pasting the CFRP composite (Sika Wrap-230C) to the SHS steel was the Sikadur330. This type of adhesive is a two-part system: hardener and resin.

\section{Numerical Simulation}

\section{Method Description}

To model the steel frames, three dimensional (3D) simulation using ANSYS software was performed. The SHS steel frames, CFRP sheets, and adhesive were simulated by using the 3D solid ten-node element 187 in ANSYS software. This element is shown in Figure 1. Nonlinear static analysis was carried out to simulate the failures. In this case, the load was applied incrementally until the plastic strain in an element reached to its ultimate strain (element is "killed"). Linear and nonlinear properties of materials were defined based on the stress-strain curves. The steel frames were defined as the materials having nonlinear properties which were obtained from the experimental values in Keykha et al. [7]. The adhesive was defined as the materials having linear properties. Also, CFRP material properties were defined as linear and orthotropic because CFRP materials have linear properties and they were unidirectional [17-23]. For meshing, the map meshing was used. Therefore, for analysis of the specimens from the solid element 187 with the mesh size of 25 was used [17-23].

\section{Validity of Software Results}

In this research, the software results have been validated and calibrated by the experimental results of Sundarraja et al. [15]. In numerical method, the beams loaded as in experimental [15] and the same conditions were analyzed (as shown in Figures 2-4).
The results of the analyzed beams (beam CB-2 and FWB-L1) show that, there is a good agreement between experimental and numerical values, with comparing moment-deflection curve as shown in Figure 5.

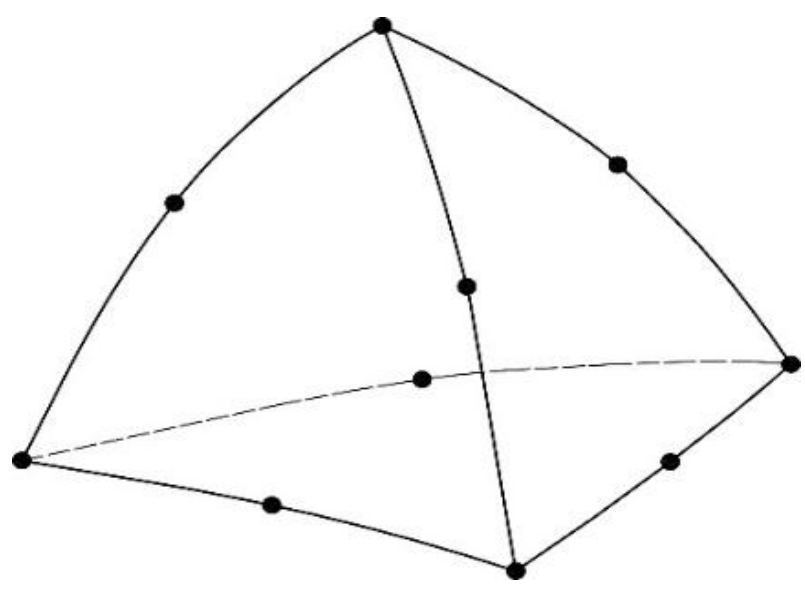

Figure 1. Solid Elements 10 Nodes 187 (in ANSYS software) used for Modeling the Specimens
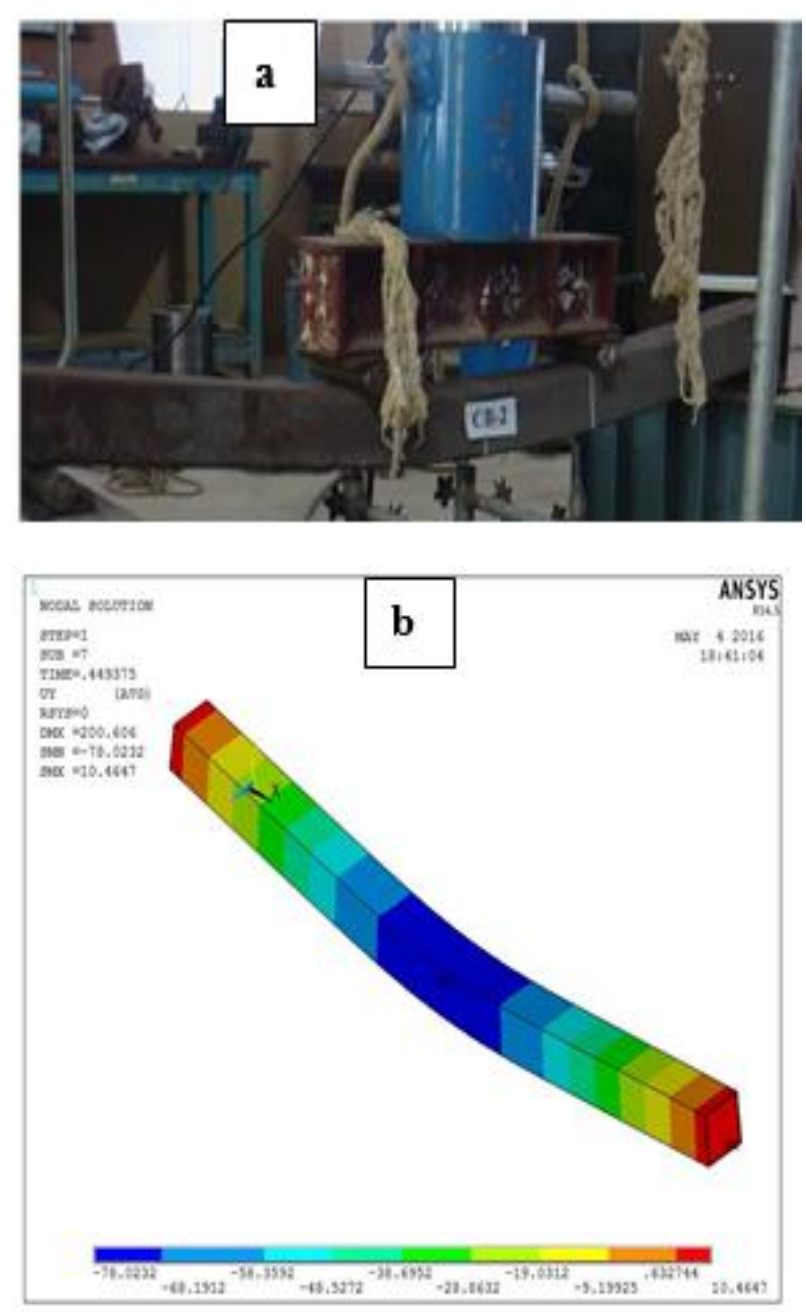

Figure 2. Failure Mode of Beam CB-2. (a) Experimental [15]. (b) Numerical simulation 

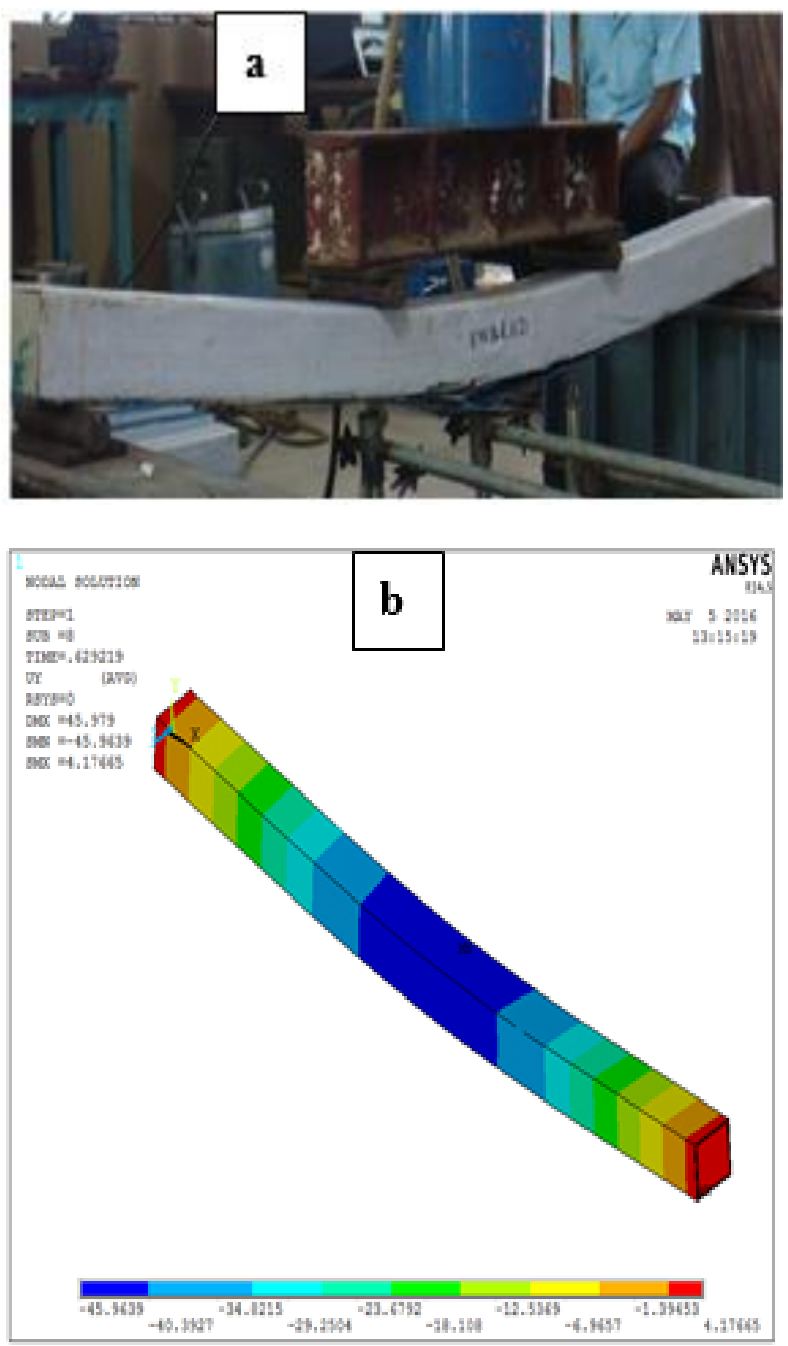

Figure 3. Failure Mode of Beam FWB-L1; (a) Experimental [15]. (b) Numerical simulation

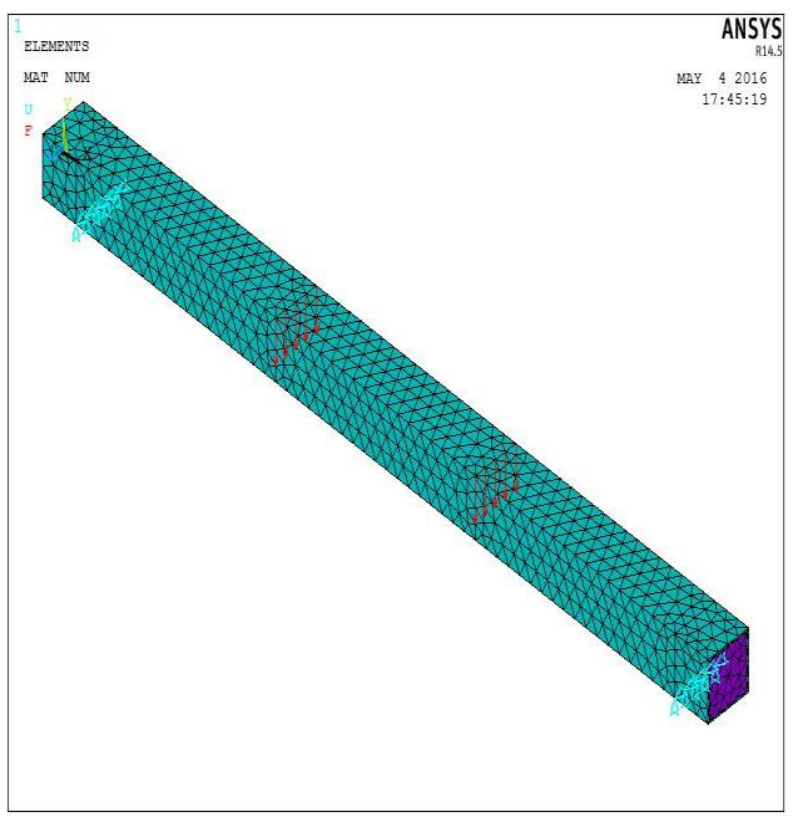

Figure 4. Typical Loading and Boundary Condition Assigned to Beam in ANSYS
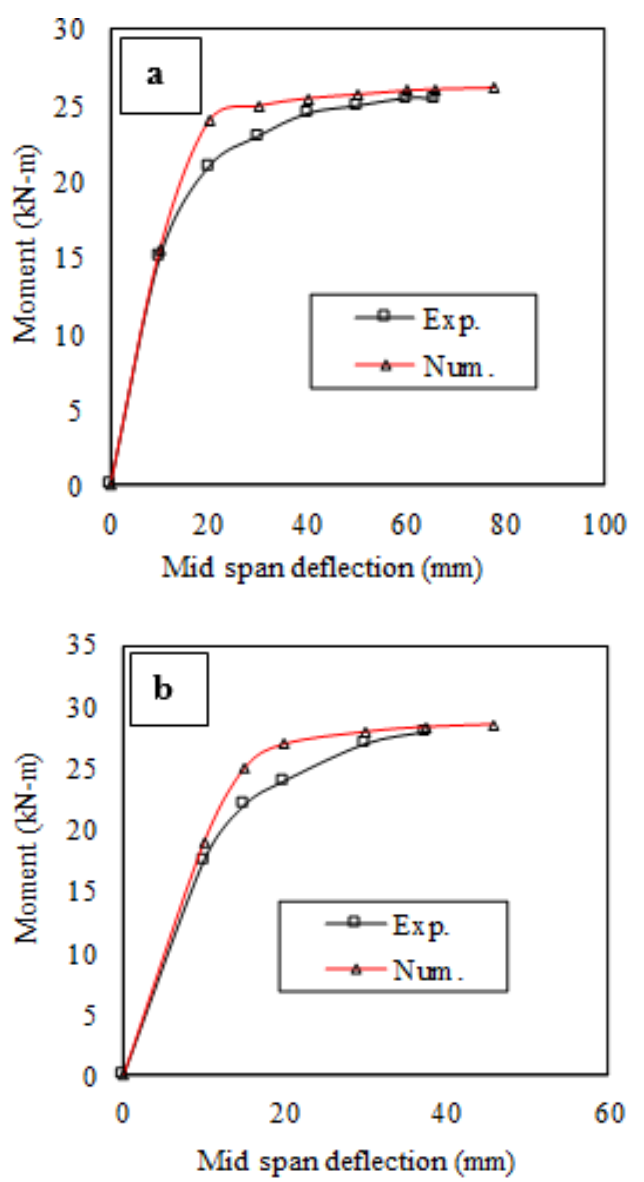

Figure 5. Moment-deflection curve. (a) Specimen BC2. (b) Specimen FWB-L1

\section{Description of Specimens}

The analyzed frames include one specimen without strengthening as a control specimen, one specimen having initial deficiency without strengthening, and five strengthened specimens having an initial deficiency. These specimens were strengthened with one and two CFRP layers. CFRP layers had a different coverage length and different width. The CFRP sheets were pasted in the beam center of the SHS steel frame on the bottom or two vertical sides (beam web) as shown in Figs. 6a and b, respectively. To determine the percentage of increase or decrease in the ultimate load capacity of the strengthened steel frames, one specimen without initial deficiency was considered as control specimen without CFRP strengthening. Also, one specimen having an initial deficiency without strengthening was analyzed, to determine the recovery percentage in the ultimate load capacity of the strengthened specimens. To identify the specimen easily, the SHS steel frames were designated by the names FC0, DFC0, DFC1700-200, DFC1-1000-100, DFC1-1000-200, DFC21000-200, and DFC1-1500-200. For example, the specimen DFC1-1000-100 indicates that it is a SHS steel frame having initial deficiency strengthened by one layer and $1000 \mathrm{~mm}$ CFRP length on the bottom. 
In this specimen, the width of CFRP sheet is 100 mm (see Figure 6a). Similarly, the specimen DFC11000-200 indicates that it is a SHS steel frame having initial deficiency strengthened by one layer and $1000 \mathrm{~mm}$ CFRP length on the bottom. In this specimen, the width of CFRP sheet is $200 \mathrm{~mm}$ (see Figure 6b). The specimen DFC2-1000-200 is such as the specimen DFC1-1000-200 but was strengthened by two CFRP layers. The specimen DFC1-1500-200 specifies that it is a SHS steel frame having an initial deficiency strengthened by one layer and 1500 mm CFRP length on the bottom. In this specimen, the width of CFRP sheet is $200 \mathrm{~mm}$. The control specimen is named FC0 (the SHS steel frame without CFRP strengthening). The specimen DFC0 is a specimen having an initial deficiency without CFRP strengthening.
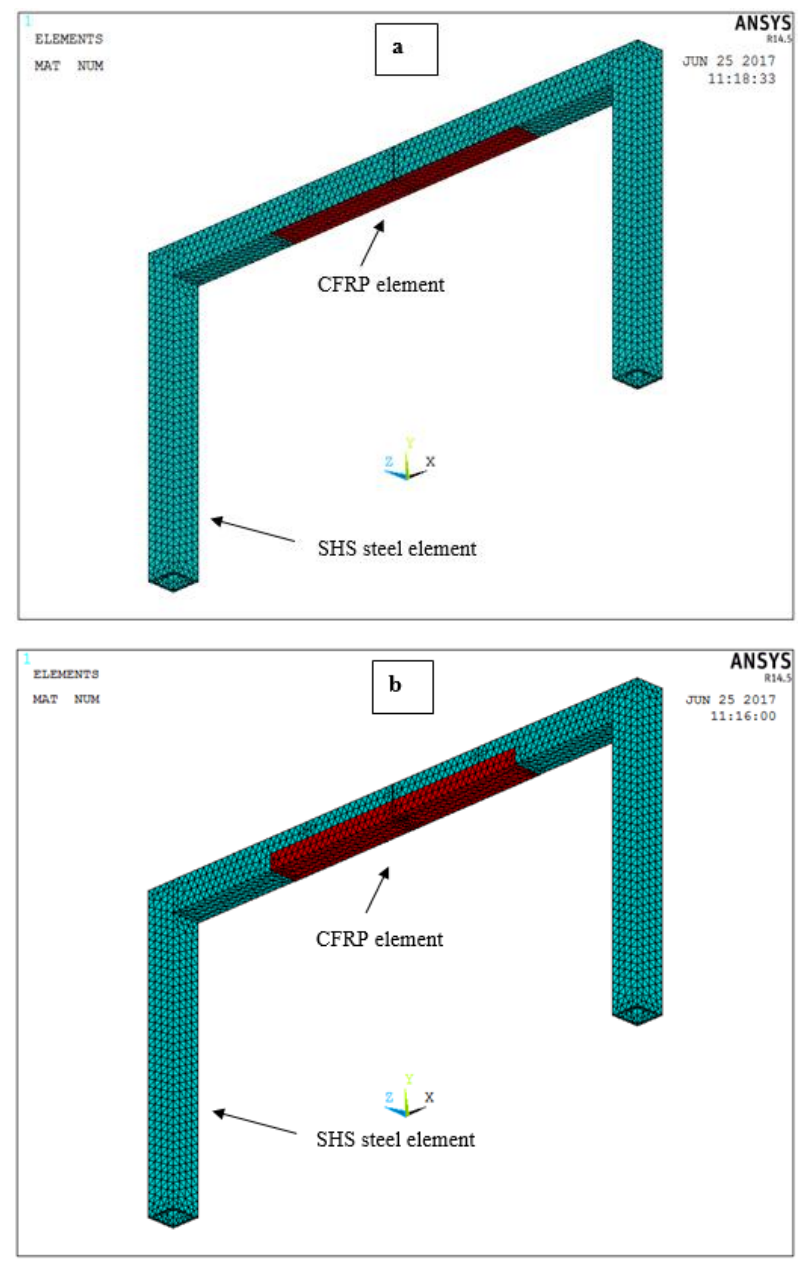

Figure 6. Finite Element Modeling of Specimens. (a) Specimen DFC1-1000-100. (b) Specimen DFC1-1000-200

\section{Model Description}

Nonlinear finite element models were prepared using ANSYS software to investigate the structural behavior of the SHS steel frames having initial deficiency strengthened using CFRP sheets on bottom and two vertical sides. All models were prepared as the SHS steel frames with fixed ends that were under two-point load at equal distance from each their column (700 mm distance). Figure 7 shows the condition of the SHS steel frames having initial deficiency and CFRP strengthening scenario adopted in this study. For example, Figure 8 shows the 3D finite element model of the specimen prepared using ANSYS software (specimen DFC0). In finite element models, dimensions of the initial deficiency were $100 \mathrm{~mm} \times 50 \mathrm{~mm} \times 5 \mathrm{~mm}$ (see Details A in Figure 8). The loads (point loads) are gradually increased until the strengthened SHS steel frames achieved their ultimate load capacity. As mentioned in the materials section, the SHS steel having a dimension of $100 \mathrm{~mm} \times 100 \mathrm{~mm}$ was used in this study. The thickness of column and beam of the SHS steel frames was 10 and $5 \mathrm{~mm}$, respectively. This design was done to ensure weak beam-strong column mechanism for ductile frames.

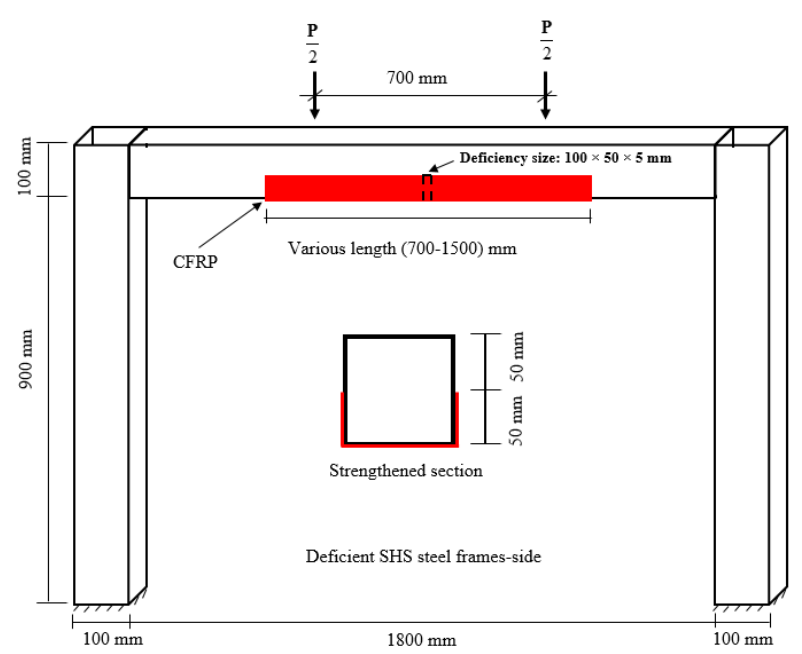

Figure 7. Boundary Conditions of a Deficient SHS Steel Frames Strengthened using CFRP

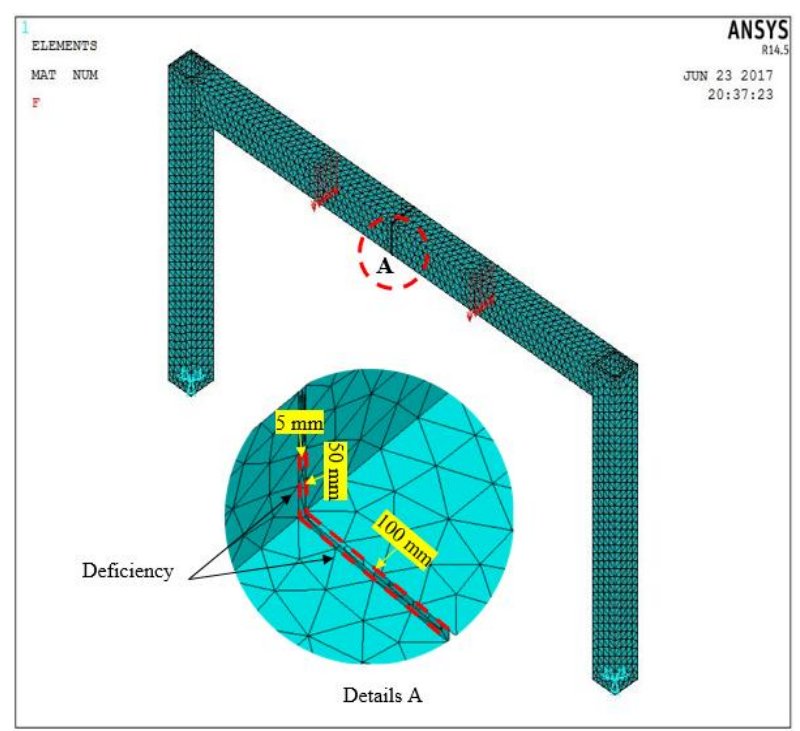

Figure 8. Finite Element Modeling of Specimen DFC0 


\section{Results and Discussions}

\section{Ultimate Load Results}

Table 1 shows the numerical analysis results of specimens with one and two layers of CFRP sheet. The results showed that CFRP sheet can recover the ultimate load capacity of the SHS steel frames having initial deficiency. When the width of CFRP sheet was $100 \mathrm{~mm}$, CFRP is not very effective in the ultimate load capacity recovery, since the deficiency was not completely covered by the CFRP sheet. Increasing the number of layer to two did not increase the ultimate load capacity of the SHS steel frames having initial deficiency, because one layer of CFRP composite could completely recover the ultimate load capacity of these frames. The maximum percentage of recovery in the ultimate load capacity happened for the specimen DFC2-1000-200 (33.55\%).

\section{Failure Modes}

All SHS steel frames were under two-point load on their top surface until failure. The failure modes of the SHS steel frames having initial deficiency are the same, for example, the failure modes of two specimens are shown in Figures 9a and b. As shown in Figures 9a and $\mathrm{b}$, the failure mode of the specimens were observed in the deficiency location for the deficient SHS steel frames at the ultimate load capacity (the ultimate load capacity of the SHS steel frames is shown in Table 1).

\section{Conclusions}

In this research, CFRP sheets were applied with different coverage length, width, and number of layers on the bottom and the two vertical sides of the SHS steel frames to enhance the structural performance. Based on the analyzed specimens, the failure modes, the ultimate load capacity, the percent of increase or decrease in ultimate load capacity, and the percent of recovery in the ultimate load capacity of the SHS steel frames were discussed.
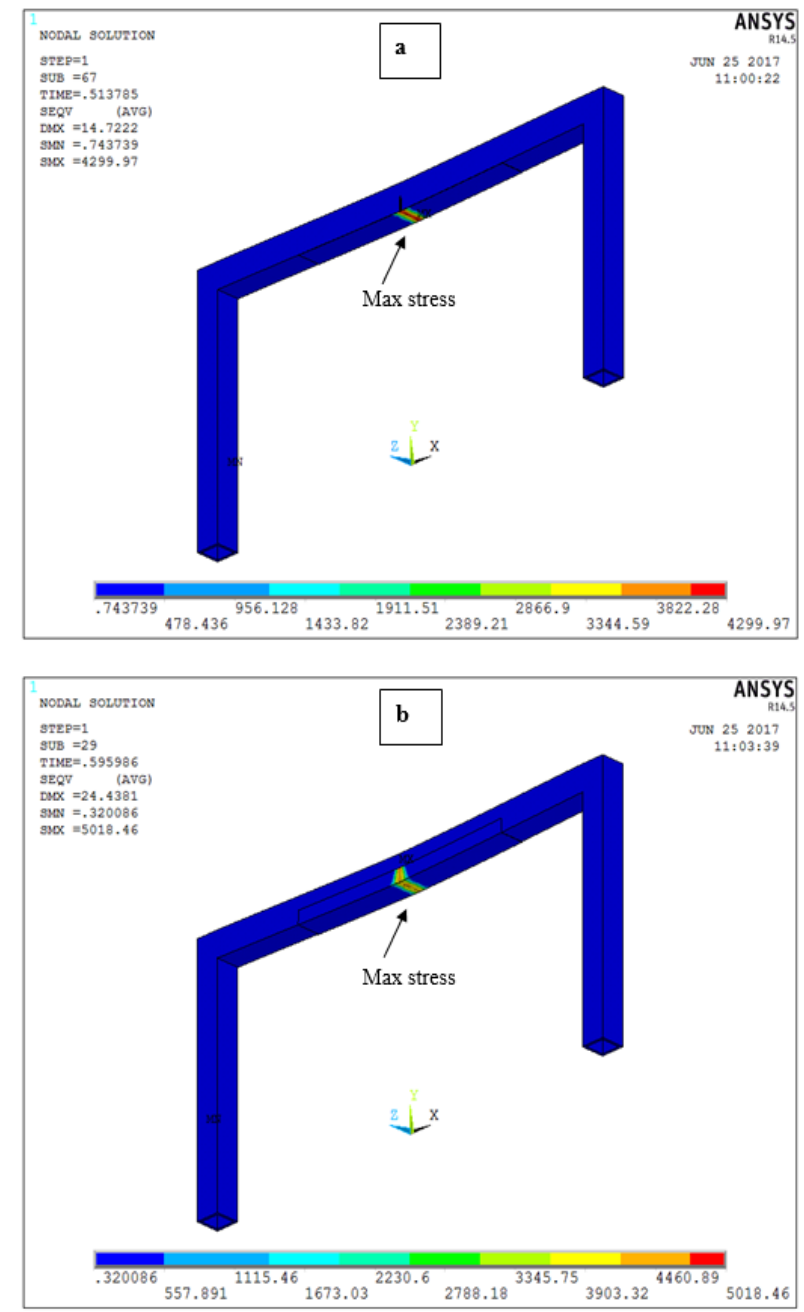

Figure 9. Failure mode of the specimens. (a) Specimen DFC1-1000-100. (b) Specimen DFC1-1000-200.

Based on obtained results, the following conclusions were drawn:

- CFRP sheet can recover the ultimate load capacity of the SHS steel frames having initial deficiency.

- When the width of CFRP sheet was $100 \mathrm{~mm}$ due to the deficiency was not completely covered by CFRP sheet, CFRP is not very effective in the ultimate load capacity of the SHS steel frames strengthened with one and two CFRP layers.

Table 1. Specimen Details and Analysis Results

\begin{tabular}{cccccc}
\hline $\begin{array}{c}\text { Designation of } \\
\text { frames }\end{array}$ & $\begin{array}{c}\text { Number of CFRP } \\
\text { layers }\end{array}$ & $\begin{array}{c}\text { Length and width } \\
\text { of CFRP }(\mathrm{mm})\end{array}$ & $\begin{array}{c}\text { Ultimate load } \\
\text { capacity } \\
(\mathrm{kN})\end{array}$ & $\begin{array}{c}\text { \% of increase or } \\
\text { decrease in ultimate } \\
\text { load capacity }\end{array}$ & $\begin{array}{c}\text { \% of recovery in } \\
\text { ultimate load } \\
\text { capacity }\end{array}$ \\
\hline FC0 & 0 & 0 & 118.75 & NA & NA \\
DFC0 & 0 & 0 & 83.30 & -29.85 & NA \\
DFC1-700-200 & 1 & $700 \times 200$ & 116.44 & -1.95 & 27.90 \\
DFC1-1000-100 & 1 & $1000 \times 100$ & 102.76 & -13.47 & 16.38 \\
DFC1-1000-200 & 1 & $1000 \times 200$ & 119.20 & +0.38 & 30.23 \\
DFC2-1000-200 & 2 & $1000 \times 200$ & 123.14 & +3.70 & 33.55 \\
DFC1-1500-200 & 1 & $1500 \times 200$ & 119.52 & +0.65 & 30.50 \\
\hline
\end{tabular}


- The ultimate load capacity of the SHS steel frames having initial deficiency with increasing number of CFRP layers more than one layer had not much increase, because one layer of CFRP composite could completely recover the ultimate load capacity of these frames.

- The maximum percentage of recovery in the ultimate load capacity happened for the specimen DFC2-1000-200 (33.55\%).

- The failure modes of all SHS steel frames having initial deficiency were the same and were observed in the deficiency location at the ultimate load capacity.

\section{References}

1. Teng, J.G. and Hu, Y.M., Behaviour of FRPJacketed Circular Steel Tubes and Cylindrical Shells under Axial Compression, Construction and Building Materials, 21(4), 2007, pp. 827838.

2. Bambach, M.R., Jama, H.H., and Elchalakani, M., Axial Capacity and Design of Thin-Walled Steel SHS Strengthened with CFRP, ThinWalled Structures, 47(10), 2009, pp. 1112-1121.

3. Haedir, J. and Zhao, X.L., Design of Short CFRP-Reinforced Steel Tubular Columns, Journal of Constructional Steel Research, 67(3), 2011, pp. 497-509.

4. Fanggi, B.A.L. and Ozbakkaloglu, T., Square FRP-HSC-Steel Composite Columns: Behavior under Axial Compression, Engineering Structures, 92, 2015, pp. 156-171.

5. Ozbakkaloglu, T. and Xie, T., Behavior of Steel Fiber-Reinforced High-Strength Concrete-Filled FRP Tube Columns under Axial Compression, Engineering Structures, 90, 2015, pp. 158-171.

6. Kim, Y.J. and Harries, K.A., Behavior of TeeSection Bracing Members Retrofitted with CFRP Strips Subjected to Axial Compression, Composites Part B: Engineering, 42(4), 2011, pp. 789-800.

7. Keykha, A.H., Nekooei, M., and Rahgozar, R., Experimental and Theoretical Analysis of Hollow Steel Columns Strengthening by CFRP, Civil Engineering Dimension, 17(2), 2015, pp. 101-107.

8. Keykha, A.H., Nekooei, M., and Rahgozar, R., Analysis and Strengthening of SHS Steel Columns using CFRP Composite Materials, Composites: Mechanics, Computations, Applications. An International Journal, 7(4), 2016, pp. 275-290.

9. Deng, J., Lee, M.M., and Moy, S.S., Stress Analysis of Steel Beams Reinforced with A Bonded CFRP Plate, Composite Structures, 65(2), 2004, pp. 205-215.
10. Youssef, M.A., Analytical Prediction of the Linear and Nonlinear Behaviour of Steel Beams Rehabilitated using FRP Sheets, Engineering Structures, 28(6), 2006, pp. 903-911.

11. Islam, S.Z. and Young, B., Strengthening of Ferritic Stainless Steel Tubular Structural Members using FRP Subjected to Two-FlangeLoading, Thin-Walled Structures, 62, 2013, pp. 179-190.

12. Al-Zubaidy, H., Al-Mahaidi, R., and Zhao, X.L., Finite Element Modeling of CFRP/Steel Double Strap Joints Subjected to Dynamic Tensile Loadings, Composite Structures, 99, 2013, pp. 48-61.

13. Chahkand, N.A., Jumaat, M.Z., Sulong, N.R., Zhao, X.L., and Mohammadizadeh, M.R., Experimental and Theoretical Investigation on Torsional Behaviour of CFRP Strengthened Square Hollow Steel Section, Thin-Walled Structures, 68, 2013, pp. 135-140.

14. Photiou, N.K., Hollaway, L.C., and Chryssanthopoulos, M.K., Strengthening of an Artificially Degraded Steel Beam utilizing a Carbon/Glass Composite System, Construction and Building materials, 20(1), 2006, pp. 11-21.

15. Sundarraja, M.C. and Prabhu, G.G., Finite Element Modeling of CFRP Jacketed CFST Members under Flexural Loading, Thin-Walled Structures, 49(12), 2011, pp. 1483-1491.

16. Al Zand, A.W., Badaruzzaman, W.H., Mutalib, A.A., and Qahtan, A.H., Finite Element Analysis of Square CFST Beam Strengthened by CFRP Composite Material, Thin-Walled Structures, 96, 2015, pp. 348-58.

17. Keykha, A.H., Nekooei, M., and Rahgozar, R., Numerical and Experimental Investigation of Hollow Steel Columns Strengthened with Carbon Fiber Reinforced Polymer, Journal of Structural and Construction Engineering, 3(1), 2016, pp. 49-58.

18. Keykha, A.H., CFRP Strengthening of Steel Columns Subjected to Eccentric Compression Loading, Steel and Composite Structures, 23(1), 2017, pp. 87-94.

19. Keykha, A.H., Effect of CFRP Location on Flexural and Axial Behavior of SHS Steel Columns Strengthened using CFRP, Journal of Structural and Construction Engineering, 4(2), 2017, pp. 33-46.

20. Keykha, A.H., Numerical Investigation of SHS Steel Beam-Columns Strengthened using CFRP Composite, Steel and Composite Structures, 25 (5), 2017, pp. 593-601.

21. Keykha, A.H., Structural Behaviors of Deficient Steel Members Strengthened Using CFRP Composite Subjected to Torsional Loading, $3^{\text {rd }}$ International Conference on Mechanics of Composites Conference Proceedings, Bologna, Italy, 2017. 
22. Keykha, A.H., Finite Element Investigation on the Structural Behavior of Deficient Steel BeamColumns Strengthened using CFRP Composite, $3^{\text {rd }}$ International Conference on Mechanics of Composites Conference Proceedings, Bologna, Italy, 2017.
23. Keykha, A.H., 3D Finite Element Analysis of Deficient Hollow Steel Beams Strengthened using CFRP Composite under Torsional Load, Composites: Mechanics, Computations, Applications, An International Journal, 8(4), 2017, pp. 287-297. 